\title{
Creating an Interactive English Classroom
}

\author{
Hui Guo \\ College of Foreign Languages, Bohai University, Jinzhou, 121013, China \\ 953793256@qq.com
}

Keywords: interaction; communication; cooperative and collaborative learning

\begin{abstract}
The Communicative Approach has been introduced into the field of EFL in China since 1970s. From then on, the word "interaction" has become a term which has been much discussed. Interaction has become a very important word for English teachers and learners. In the era of communicative teaching interaction in fact is a kind of exchange of feelings, thoughts, or ideas between two or more learners. In an interactive classroom English learners are encouraged to take initiative in the study of English in order to make the learners increase their language store. This paper aims at discussing how to create an interactive English classroom so that it can contribute to English teaching and learning.
\end{abstract}

\section{Introduction}

Our age is a one of knowledge exploding. English is being learnt as a very useful tool in many countries. It has been a compulsory subject from primary schools to colleges in China since 1980s. Effective and good teaching methods have always been the pursuit of English teachers. For a long time, the English teaching in China was dominated by traditional language teaching method. Even today, the traditional way still plays an important role in the foreign language teaching. Traditional English language teaching in China is dominated by a teacher-centered, examination-orientated and grammar-based method. Learning has been seen as the reflex of teaching, the action of the teacher as requiring a corresponding reaction on the part of the learner. In this way students are passive receivers of knowledge and they mainly learn through repetition and memorization. However, in recent years communicative language teaching has been mentioned and used in the classroom in China. There have been proposals to allow learners to take initiative. Thus how to create the interactive classroom in order to make initiative be effectively exercised in the English classroom has become very important in English teaching and learning.

\section{Interactive Language Teaching}

Interaction is the collaborative exchange of thoughts, feelings, or ideas between two or more people, resulting in a reciprocal effect on each other. Theories of communicative competence emphasize the importance of Interaction as human beings use language in various contexts to negotiate meaning, or simply stated, to get an idea out of one person's head and into the head of another person and vice versa [1].

Brown's theory has been agreed to by other theorists such as Mary Finocchiaro and Christopher Brumfit. A language classroom should be interactive because students can increase their language knowledge through interaction when they listen to or read authentic English materials. Students learn English by using it. In interaction, students can use all they possess of the language--all they have learned or casually absorbed--in real life exchanges where expressing their real meaning is important to them. They thus have experience in creating messages from what they hear, since comprehension is a process of creation and in creating discourse that conveys their intentions. Students can master English by using it when they pay attention to authentic messages especially when the messages contain information of interest to speaker and listener in a situation of importance to both. Exchanging is the basic matter in discourse.

Interaction involves not just expression of one's own ideas but comprehension of those of others. In the course of interaction, there must be someone to transmit a message, and someone to receive it. 
One listens to others; one responds; others listen and respond as well. Teacher, students and textbook writers are the participants in the classroom interaction. They communicate with each other in various different combinations and different ways. The participants work out interpretations of meaning through this interaction. Students need to learn to listen to others, talking with others, negotiating meaning in a shared context as they learn to communicate because communication must be interaction between people who have something to share [1].

Thus, it is a crucial task for an English teacher to create an interactive classroom.

\section{Problems in English Teaching and learning}

With the acceleration of globalization, English learning is becoming more and more important and popular not only in China but also all over the world. Although English as a foreign language has been learnt for many years in China, the learning result is not satisfying. Of course there are many reasons for that. Most Chinese students do not have chances to communicate with English speaking people, and they do not have natural environment to learn English. They just learn English from their teachers and their books in their school. In order to get good grades in the exams, they seldom practice speaking and listening. Also sometimes it is difficult for them to under stand those materials written by native writers because most learners are unfamiliar with the custom and culture of the western countries. However, good teaching and learning method may play the most important role in English teaching and learning [2].

Nowadays in China, English is still taught in the traditional ways which is not the best way for students to master English as whole. In such kind of class both the teacher and the students focus their attention to grammar, language points and translation. English is not learnt as a whole language. The reasons for this are complex. In some aspects, teachers' control of the classes is admirable because of the big size classroom. Besides, traditional method is easier for teachers. As a result, a lot of students have difficulties in improving their four basic skills which are listening, speaking, reading and writing, especially listening and speaking. Many students feel it very difficult to communicate with English speaking people after six years or even more years' learning of English.

In traditional language teaching, a teacher's role is usually expected as a master controller. The teacher is always in charge of every moment in the classroom. In addition the teacher always determines what the students do, when and what they should speak, and what language forms they should use. The teacher can also predict the answers to the question he or she asks because everything is mapped out ahead of time, with no room for the students to create his or her own language. Most of the teachers are limited to exam-oriented teaching practice, and they focus most of their time and energy on grammar and language points because they are lack of new ideas of teaching methodology. Under the pressure of exams and because of improper methods, many students feel English is very difficult to learn and some of them even lose interest for learning English. Thus to create an interactive classroom to make the students to practice the four skills is very urgent.

\section{The Teacher's Adoption of Strategies to Help Interactivity in Class}

Looking at recent developments in teaching foreign languages, an evolution in the role of the teacher can be observed. In the traditional teaching method, the teacher is regarded as the authority, with students as the followers. In order to encourage classroom interaction, the teacher should abandon the role of the expert who is in front of the class. The teacher has to step down from the front platform, for effective teaching. For effective teaching, English teachers should take the following points into consideration.

(1) Changing the role of the teacher. First of all the English teachers has to turn from a master controller into a wise controller who can carefully and successfully project how a technique or an activity will proceed, specify directions to be given. The teacher has to know where control is needed and where control should be relaxed. Only by controlling the pace of class wisely can the 
activities run efficiently. And only the teacher steps away from the position of authority, can the real communication between the teacher and the students be achieved.

Next the teacher has to be a good manager. It is the teacher's role to plan lessens and modules and courses and he has to keep the students pointed toward goals. After he designs tasks, he has to organize them so that students can perform in class smoothly. The teacher can walk around the classroom to notice how the students behave while the students are doing activities. The teacher has to make sure that the students are doing the right tasks. In a word, the teacher is responsible for the tasks to be completed smoothly.

Then the teacher has to be a resource provider. This role requires the teacher allow his students to find their own ways to learn English successfully. The teacher plays this role well by allowing students to discover language through using it pragmatically rather than telling them about the language. When students have any questions the teacher is hoped to be "there" for advice and counsels and to be good and convenient resource for the students. English teachers must be ready to explain English knowledge as well as make their students learn about English and learn to use it properly.

Besides, the teacher is considered to be a participant. Interactive methods encourage both the students and the teacher to be participants. After the instructions are given and the activities started, there is no difficult or new language points to explain in front of the class, the teacher can join one or two groups to be an ordinary participant. This will encourage students a lot because they have a better group member and it can make them more confident in the group work. In the meantime, students can feel at home with their teacher.

Finally as it is believed one of the most important jobs of a teacher is to assess. So the role of an assessor must be played well by an English teacher. For an assessor two things will be mainly done, that is, correcting mistakes and giving proper feedbacks. Harmer suggested that correcting should be gentle. Gentle correcting involves showing that incorrectness has occurred, but not making a big fuss about it. Students can not make much progress without knowing their mistakes, so giving feedbacks is very necessary. However, it is very discouraging for the teacher to be critical while making feedbacks.

In addition teachers also have to create positive learning atmosphere, make use of different strategies to motivate students, guide them to plan and take in charge of their own learning as well as assessing their own learning. Good teachers not only have to pay attention to students' different interests and their potential capabilities but also have to be fair while assessing $[1,5]$.

(2) Having a clear plan. Having a plan of action means that the teacher knows what he or she wants to do in the classroom. Proper lessen planning is the essential part to achieve the goals. In other words, the teacher must be clear about the aim to be achieved, materials to be learned, act ivies to be taken place and techniques to be used in the class. A clear lessen plan makes the teacher know the learning aims and the language contents of the class. A clear lessen plan also helps the teacher to predict the difficulties and problems that may appear in the class. Besides, a clear lessen plan can give the teacher confidence when he steps into the classroom and meets the students. Students are clever enough to know whether their teacher has prepared his lessen well or not, and it will influence the students' mood in class learning and class behavior even after class behavior. As it is known, many communicative tasks involve in face-to-face encounters in the classroom. Thus the teacher has to have something to communicate with the students and have something that can make students engage in communication.

But having something to communicate is not the same thing as actually communicating it. In order to achieve this, the plan of action must be carried out in a context of interaction. The teacher must engage in the sort of interaction with the students which will enable communication to take place.

Frequently, learners have differing perspectives on the content of the lesson from that of the teacher. One way to go about resolving this difficulty is to provide students with a clear idea of the purpose and objectives of the lesson. The teacher's lesson plan should not be a secret or a mystery. Specifying as clearly as possible the setting, the situations, the expected roles, the possible 
outcomes of the interaction with peers and teaches - before, while and after the task is conducted will reduce the conflicting perspectives.

(3) Creating an interactive classroom atmosphere. Having a good and clear plan is far from enough for an interactive classroom. Course goals are to develop students' language skills. And it is the development of skills that needs a right classroom atmosphere.

In order to create the effective classroom interaction, first of all, the teacher has to be open-minded, change his traditional concepts of teaching. In the traditional teaching, he is a master having a sense of threatening sense. However, in an interactive classroom he has to create a non-threatening atmosphere in order to make students join the activities eagerly. Only in the non-threatening atmosphere can the input of the language message reach the part of the brain responsible for language acquisition.

Another feature for the teacher to keep in mind is to show tolerance towards students' errors. To many teachers, this might appear to conflict with their pedagogical role, which has traditionally required them to evaluate all learners' performance according to clearly defined criteria. What is more important is if a teacher does not show tolerance towards errors may end up hindering communication, and students may conclude that correctness is more important than communication.

Finally, the teacher must provide meaningful input and allow sufficient practice before requiring learners to perform. Because of either the materials being used or the training of the teacher or students' expectation, some repetition is often expected in language classrooms. Meaningfulness can be greatly enhanced when the teacher makes use real tasks and authentic texts. Only in this way can not students go blank when they listen to native speech and talk with native speakers.

(4) Encouraging cooperative and collaborative learning. Cooperative learning should be considered as a strategy for group management in which mixed-ability groups interact. When students work together in pairs and groups, they share information and come to each other's help. They are a team whose players have a common goal and they must play their best to achieve the goal successfully [3]. Greater hope of success reduces anxiety and can result in increased participation and language learning. Even if a mistake is made, the pressure is shared and no student in the group will suffer from loss of face. Research has shown an advantage for cooperative learning on such factors as "promoting intrinsic motivation, heightening self-esteem, creating caring and altruistic relationships, and lowering anxiety and prejudice" [4]. Interaction gives students practice in communicating and negotiating meanings, at the same time, allows them to establish how well they can understand and make themselves understood [5].

In traditional language classes, the teacher is dominant explaining grammar points and each student might get a few seconds of a class period to speak and less time to talk each other. Cooperative learning helps to solve the problem and offers many opportunities for the students to talk in class. This generates interactive English and increases students' motivation, because group work places responsibility for action upon each student of the group. In addition small groups help students with varying abilities to accomplish separate goals because each student's ability is unique. In cooperative learning, when students work in a group, there are more possibilities of providing a correct acceptable answer. Students have time to think, opportunities to rehearse and receive feedback [6]. Cooperative learning makes uses of many techniques such as games, interview, brainstorming, jigsaw, roundtable, role-play and simulations, all of which could potentially involve the students greatly and make them interact more in order to carry out a task.

(5) Questioning strategies. One of the most key points to create interactive English classroom is the initiation of interaction by the teacher. And one of the best ways for the initiation of the interaction is questioning strategies. Teachers' proper questions will lead to good communication. Teachers' questions can give students opportunities to produce good language without taking risks or making unnecessary mistakes. Students, especially Chinese students, often are afraid to initiate conversations or topics for discussion because of our national characters. Thus teachers' proper questions are very important for the classroom interaction. It also can help students to interact among themselves. Another function of the teacher's question is that the teacher can give immediate feedback to the students. The teacher can learn about linguistic and content difficulties through 
asking questions. Teacher questions provide the opportunities to find out what they think by hearing what they say $[7,8]$.

Of course teachers have to pay attention to what kinds of questions to ask and try to avoid asking certain kinds of questions that may actually discourage interactive learning, for example, too much class time spent on display questions, questions that insult students intelligence by being so easy and obvious to every one in the class, and vague questions and too many rhetorical questions. In the meanwhile the teacher has to be careful who to ask. A good English teacher must make sure that he challenges his students sufficiently by asking good and proper questions but without overwhelming them.

(6) Becoming a guide. One of the most obvious features about the development of communicative ability is that it occurs through processes inside the learner. However, this does not mean that the teacher is not necessary. The teacher must be prepared to subordinate his own behavior to the learning needs of his students, helping where necessary. He may move about the classroom in order to monitor the strengths and weaknesses of the students. He must be always ready to be there to offer help when needed.

The teacher can act as a guide to provide instruction, help students learn, allow for opportunities for real communication with and among students, and control over the students' performance, evaluating and correcting it. The teacher should not give up control because he must perceive classroom events, diagnose their meanings and react appropriately.

\section{Conclusion}

Students learn English by using it. In an interactive classroom students interact in English, perhaps painstaking at first, but gradually they will get confidence. With new activities to study, an unimaginative and conventional language classroom can gradually be transformed. New roles of the teacher can be played by better and more responsible teachers. An atmosphere of excitement can be created where confident students initiate and cooperate in imaginative activities, sharing with each other real messages in authentic and exhilarating interaction. Practical and effective communicative activities are sure to enable students to understand, simulate and use the language material in the form of communication.

\section{References}

[1] H. D, Brown, "Teaching by Principles. An Interactive Approach to Language Pedagogy," 2d ed. Englewood Cliffs, NJ: Prentice Hall Regents, 2001.

[2] F. Ungerer, H. J. Schmid, "An Introduction to Cognitive Linguistics," Foreign Language Teaching and Research Press, 2011.

[3] R. H, Kristen, "Lessens Learned from Experiential Group Work Learning," Published on line:http://www. Tandfonline. Com/loi/wswg 20, 2014.

[4] Oxford, Rebecca, "Cooperative learning, collaborative learning, and interaction: Three communicative strands in the language classroom", Modern Language Journal, vol. 81, no. 3 pp443-456, 1997.

[5] Qiang Wang, "A Course in English Language Teaching," High Education Press, 2006.

[6] L. Gurzynski-Weiss, A. Revesz, "Tasks, teacher feedback, and learner modified output in naturally occurring classroom interaction," Language Learning, vol.62, no 3, pp851-879, 2012.

[7] z. Dornyei, "Research Methods in Applied Linguistics: Quantitative, Qualitative and Mix Methodologies," ( 2nd Edition), Oxford University Press, 2011.

[8] A. Jonsson, "Facilitating Productive Use of Feedback in Higher Education," Active Learning in Higher Education, vol. 14, no.1, pp63-76, 2012. 